\title{
The Perception of Word Primary Stress by European Portuguese
}

\author{
Adelina Castelo
}

\section{Introduction}

This paper presents the results of a pilot experiment, aiming to understand the role of lexical, morphological and phonological cues in the perception of word primary stress by EP native speakers.

As theoretical framework I use some of the ideas adopted in Peperkamp and Dupoux (2002), namely that the speech perception is influenced by the phonology of the listener's native language and that we can "gain insight into the nature and content of the phonological representation by conducting experiments in adults" (Peperkamp and Dupoux 2002: 206). I also assume that the "mistakes"1 caused in the perception by a "manipulation" of a certain variable reveal the importance of that variable, and that the phonetic cues associated with word primary stress are the usual ones. ${ }^{2}$

The hypothesis underlying this work is that morphological and lexical markedness as well as vowel reduction are important cues to the perception of word primary stress by EP native speakers, and that, consequently, the manipulation of those variables will lead to some perception mistakes.

The most recent works (Mateus and Andrade 2000, Mateus 2003 and Vigário 2003) consider that the word primary stress's position is 
essentially determined by morphological and lexical knowledge of the language.

The Portuguese word primary stress may fall on one of the three last syllables. There are two stress subsystems: the nominal one and the verbal one (see Table 1). In the noun system, the primary stress falls either on the last vowel of the derivational stem (the unmarked pattern) or on the penultimate vowel of this domain, whenever the last vowel is lexically marked as unstressable (the marked pattern).

The verb system is more complex. It contains no vowels lexically marked as unstressable, but the verb tenses present three different stress patterns: present tenses' forms are always stressed on the penultimate syllable of the word (except for inflected and uninflected Infinitive, which are always stressed on the theme vowel); past tenses' forms are stressed on the theme vowel; and future tenses' forms are stressed on the first vowel of the tense-mood-aspect morpheme.

Table 1: Portuguese word primary stress ${ }^{3}$

\begin{tabular}{|c|c|c|}
\hline NOUN SUBSYSTEM & Unmarked pattern & Marked pattern \\
\hline $\begin{array}{l}\text { With } \\
\text { class marker }\end{array}$ & 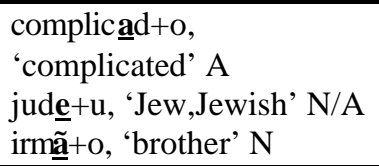 & $\begin{array}{l}\text { simpátic+o, ‘sympathetic' A } \\
\text { armári+o, 'cupboard' N } \\
\text { órfã+o, 'orphan(m)’ N/A }\end{array}$ \\
\hline $\begin{array}{l}\text { Without } \\
\text { class marker }\end{array}$ & $\begin{array}{l}\text { café, 'coffee' N } \\
\text { Portugalal, 'Portugal' N } \\
\text { jardịm, 'garden' N }\end{array}$ & $\begin{array}{l}\text { tạaxi, 'taxi' } \mathrm{N} \\
\text { fácil, 'easy' } \mathrm{A} \\
\text { garagem, 'garage' } \mathrm{N}\end{array}$ \\
\hline
\end{tabular}




\begin{tabular}{|c|c|c|c|}
\hline \multicolumn{2}{|c|}{ VERB SUBSYSTEM } & \multicolumn{2}{|c|}{ Unmarked pattern } \\
\hline \multirow{5}{*}{$\begin{array}{c}\text { Present } \\
\text { tenses }\end{array}$} & Uninflected Infinitive & \multicolumn{2}{|c|}{ gost $\underline{a}+r$, 'to like' V } \\
\hline & Inflected Infinitive & \multicolumn{2}{|c|}{ gosta $\underline{a}+\mathrm{r}+\operatorname{mos}\left(1^{\text {st }}\right.$ plur. $)$} \\
\hline & & $1^{s t}$ sing. & $1^{s t}$ plur. \\
\hline & Present Indicative & go $\underline{\mathbf{o}} \mathrm{t}+\mathrm{O}$ & gosta + +mos \\
\hline & Present Subjunctive & gost+e & goste + mos \\
\hline \multirow{3}{*}{$\begin{array}{c}\text { Past } \\
\text { tenses }\end{array}$} & Imperfect Indicative & gosta + va & gostáa+va+mos \\
\hline & Past Perfect Indicative & goste $+i$ & gostá+mos \\
\hline & Imperfect Subjunctive & gosta $\underline{a}+$ sse & gostá + sse+mos \\
\hline \multirow{2}{*}{$\begin{array}{c}\text { Future } \\
\text { tenses }\end{array}$} & Future Indicative & gosta+rei & gosta+re+e+mos \\
\hline & Conditional & gosta+ria & gosta+ría+mos \\
\hline
\end{tabular}

As far as non-primary stresses are concerned, Portuguese presents a secondary stress in compounds, which corresponds to the previous primary stress of the compound's leftmost word - e.g., in arco-íris, 'rainbow', the primary stress of the word $\underline{a} r c o$ becomes a secondary stress.

Some literature also mentions the existence of two other kinds of word non-primary stress, highly conditioned by the phonetic production of the word: the initial stress and the echo stresses. The initial stress is an optional non-primary stress which falls on the first syllable of the prosodic word (Mateus and Andrade 2000: 125), while the echo stresses fall on every second syllable leftwards from the primary stress (Mateus and Andrade 2000: 122) - e.g. democratizaç̧ãa , 'democratization' N. However, some authors sustain that the echo stresses are usually perceived only in a very careful speech (e.g. Andrade and Viana 1999: 88).

An important phonological process related to stress is the raising and retracting of unstressed vowels, frequently referred to as "vowel reduction'. It operates differently in EP and BP (Callou and Leite 1990; 
Mateus and Andrade 2000; Mateus 2003), as you can see in Table 2.

Table 2: Vowel Reduction in EP and BP

\begin{tabular}{lll}
\hline$E P$ & stressed $V$ & all \\
& unstressed $V$ \\
\hline$[\mathbf{a}]$ & $?[\mathbf{b}]$ \\
& {$[\varepsilon, \mathrm{e}]$} & $?[\mathrm{i}] ?[\mathrm{i}]$ \\
& {$[\mathbf{0}, \mathrm{o}]$} & $?[\mathrm{u}]$ \\
& {$[\mathrm{i}]^{4},[\mathrm{u}]$, nasals } & (no change) \\
\hline
\end{tabular}

\begin{tabular}{lllll}
\hline BP & stressed $\boldsymbol{V}$ & pre-stressed $\boldsymbol{V}$ & $\begin{array}{l}\text { post-stressed } \\
\text { non-final } \boldsymbol{V}\end{array}$ & $\begin{array}{l}\text { post-stressed } \\
\text { word-final } \boldsymbol{V}\end{array}$ \\
\hline$[\mathrm{a}]$ & (no change) & (no change) & $\boldsymbol{?}[\mathrm{e}]$ \\
& $\boldsymbol{\varepsilon}, \mathrm{e}]$ & $?[\mathrm{e}] /[\varepsilon]$ & $?[\mathrm{e}]$ & $?[\mathrm{i}]$ \\
& {$[\mathrm{0}, \mathrm{o}]$} & $?[\mathrm{o}] /[\mathrm{o}]$ & $?[\mathrm{u}]$ & $?[\mathrm{u}]$ \\
& {$[\mathrm{i}],[\mathrm{u}]$, nasals } & (no change) & (no change) & (no change) \\
\hline
\end{tabular}

In BP the opposition [e]:[ع] and [o]:[0] is neutralized to $[\varepsilon]$ and [o] in the northern dialects and to $[\mathrm{e}]$ and $[\mathrm{o}]$ in the southern ones. The Bahia dialect is an 'intermediate' one, and my informant (a native speaker of this dialect) produced both mid high and mid low vowels in pre-stressed position.

In both varieties of Portuguese, there are some unstressed vowels that exceptionally do not reduce, contrary to the predictions of the vowel reduction process (see Vigário 2003). Those exceptions will be used in the corpus so as to evaluate the influence of this cue in stress perception. 


\section{Experimental Design}

In order to discover which are the most important factors in the perception of the word primary stress, I designed a corpus of one hundred Portuguese words: 83 nouns and adjectives (66 single words and 17 compounds) and 17 verbal forms. Since my main goal was to study the nominal system, the only one that has marked and unmarked stress pattern, I used only a few compounds and verbal forms. The compounds and the verbal forms will just be compared to the single words so as to see the influence of a secondary stress, and to check if the perception of verbs functions in the same way as the perception of nouns and adjectives. Although the informants were not asked if they knew the corpus's words, only very few might be unfamiliar ( $8 \%$ at most) or not often used by the informants ( $12 \%$ at most).

The variables considered in the corpus of nouns and adjectives are: (un)marked stress patterns; suffixes with(out) lexically marked stress; number of syllables available for echo stresses; secondary stress in compounds; vowel (un)reduction.

The first two variables will permit me to evaluate the importance of morphology and lexicon. If, as expected, the word primary stress is more easily identified in words with a marked stress pattern or a suffix lexically marked for stress (i.e. when the lexical exceptions override the morphological structure), then the lexical information should be more important than the morphological one.

The number of syllables available for echo stresses and the presence of secondary stresses are important to evaluate how strong 
morphological and lexical knowledge is. I expect that these "disturbing elements" do not have many consequences in the stress judgements, thus reinforcing morphological and lexical knowledge's importance.

I also included the variable vowel reduction, for this phonological process is tightly related to stress, and the neutralizations in unstressed positions seem to be an important cue for the perception of primary stress. Since vowel reduction operates differently in the two above-mentioned varieties of Portuguese, I decided to record the corpus in two versions (one in EP and the other in BP). It is expected that a smaller degree of vowel reduction will attract stress judgements, i.e., the unstressed vowels that do not suffer vowel reduction will be more frequently perceived as stressed.

Concerning this variable, I established three groups of vowels: (i) reduced vowels - unstressed vowels phonetically reduced in EP to $[\mathrm{i}, \mathrm{e}, \mathrm{u}]$ and the corresponding vowels in BP (even though these may not be phonetically reduced in this last variety); (ii) vowels not subject to reduction - [i, u, ej] and nasals; (iii)unreduced vowels - vowels that do not raise or retract in a certain unstressed position: $[\mathrm{a}, \varepsilon, \mathrm{e}, \mathrm{\rho}, \mathrm{o}$; aw, $\mathrm{ew}, \mathrm{ew}]$.

The verbal forms included in the corpus were chosen, for instance, for being related to accentually marked nouns (e.g. duvidar, 'to doubt', from dúvida, 'doubt', N...) or for having unstressed vowels which are not reduced (e.g. saltou, '(he) jumped', hospitalizar, 'to hospitalize').

\section{Experimental Procedure}

Two informants read the corpus: a female Lisbon Portuguese 
native speaker (aged 39) and a female Bahia Portuguese native speaker (aged 24). Later, ten informants heard both recorded versions. These informants were five graduated ${ }^{5}$ women aged 23 to 31 and five nongraduated women aged 19 to 24 . They were asked to identify the word main stress, without being influenced by the orthography, and I wrote down only their first answer. Although identifying word main stress is usually a task performed at school, some informants may have misunderstood the task and thus may have taken the stressed syllable to be one highlighted by some phonetic means.

They heard each word the number of times they wanted (usually only once or twice). The perceptual task of the two versions of the corpus was run on different days (except for one informant), with an interval of more than a week. The words of both versions were presented randomly and the order did not differ from one informant to the other. Some informants heard the EP version first, while others started with the BP one.

\section{Results}

The results were approached in three different ways: (i) percentage of primary stresses not perceived as such by the two groups of informants in the two versions of the corpus (see Figure 1); (ii) percentage of unstressed vowels that were perceived as stressed (in EP and BP, by groups of vowels and positions - see Tables 3 and 4); (iii) percentage of stressed vowels that were not perceived as such (in EP and BP, by groups of vowels and positions - see Tables 5 and 6). 


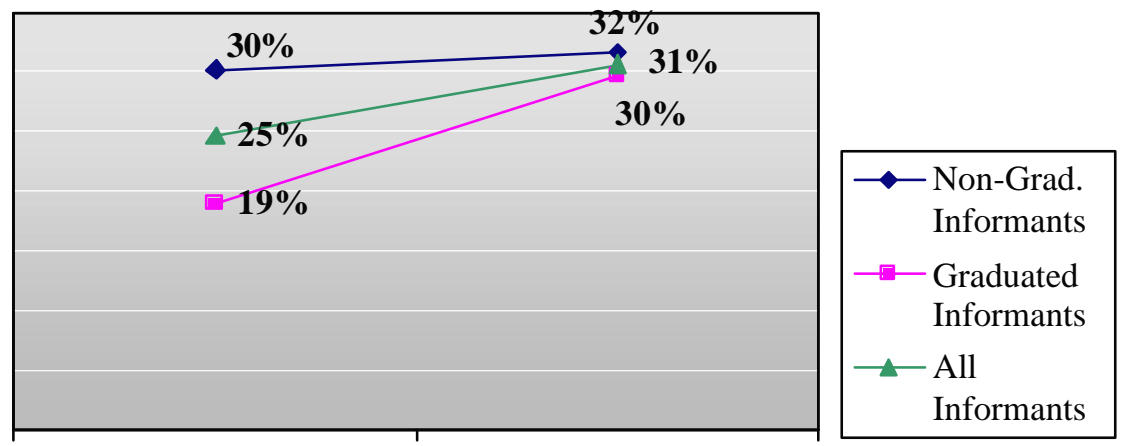

EP

$\mathrm{BP}$

Figure 1: Percentage of primary stresses not perceived as such by the two groups of informants in the two versions of the corpus

Figure 1 shows that, as expected, the graduated women correctly identified more primary stresses than the non-graduated ones. This means that more explicit knowledge of language (including better awareness of orthography and of the conditions under which the morphological and lexical patterns hold) helps the identification of word primary stress. Both groups of the informants had more difficulty in identifying the stresses heard in the BP version. Actually, the number of incorrect answers given by the two groups of informants is almost the same concerning the BP version of the corpus. In the next approaches to the results, I will not separate the results of the two groups, since both made the same kind of mistakes, although non-graduated women made more of them.

Another important fact to retain from these percentages is that the informants correctly identified most primary stresses. In fact, the highest percentage of primary stresses not perceived as such is $31.60 \%$ (nongraduated women, BP), the lowest is $19.00 \%$ (graduated women, EP) and the average of non-identified stresses in this experiment is $27.60 \%$. 
Although theses rates may be higher than expected, that they show that primary stresses are very often perceived as such. The perception results of EP and BP data present almost the same tendencies, although the rate of stresses not correctly identified is higher in the BP data.

The results presented in table 3 confirm my hypothesis about the influence of vowel reduction in stress perception. The vowels more frequently considered stressed are the unreduced ones, which is in accordance with the fact that unreduced vowels usually denote the presence of primary stress, in both varieties of Portuguese. The vowels least frequently identified as stressed are the reduced ones.

Another important aspect to take into account is the different rate of false stresses attributed to the reduced vowels in the two versions of the corpus. Hearing the EP version, informants attribute a stress only to $1.88 \%$ of the unstressed reduced vowels. When they hear the BP version, the percentage of stresses attributed to the same vowels rises to $9.56 \%$. This may be caused by the fact that unstressed vowels that are totally reduced in the EP version are little reduced (or even not reduced at all) in the BP one. Another possible cause lies in the fact that, as already suggested, for instance, by the results of Frota and Vigário (2000), there are strong secondary stresses in BP (and these can be interpreted as primary stresses by the Portuguese informants). 
Table 3: Unstressed vowels that were perceived as stressed; groups of vowels

\begin{tabular}{|c|c|c|c|c|}
\hline $\begin{array}{l}E P \\
B P\end{array}$ & $\begin{array}{l}\text { Pre-stressed } \\
\text { sequence }\end{array}$ & $\begin{array}{c}\text { Last vowel of } \\
\text { derivational } \\
\text { stem }\end{array}$ & $\begin{array}{c}\text { After last } \\
\text { vowel of } \\
\text { deriv. stem }\end{array}$ & $\begin{array}{c}\text { Rate of stresses } \\
\text { attributed to } \\
\text { each group of } V\end{array}$ \\
\hline $\begin{array}{l}\text { Reduced } \\
\text { vowels }\end{array}$ & $\begin{array}{c}62.22 \cdot 10 / 450 \\
13.55 \cdot 61 / 450 \\
(1) \\
\end{array}$ & $\begin{array}{c}0 \cdot 0 / 10 \\
10.00 \cdot 1 / 10\end{array}$ & $\begin{array}{c}1.30 \cdot 3 / 230 \\
1.73 \cdot 4 / 230 \\
(6) \\
\end{array}$ & $\begin{array}{l}1.88 \cdot 13 / 690 \\
9.56 \cdot 66 / 690\end{array}$ \\
\hline $\begin{array}{l}\text { Vowels not } \\
\text { subject to } \\
\text { reduction } \\
\end{array}$ & $\begin{array}{c}7.60 \cdot 19 / 250 \\
9.20 \cdot 23 / 250 \\
(2) \\
\end{array}$ & $\begin{array}{c}13.68 \cdot 26 / 190 \\
14.21 \cdot 27 / 190 \\
(4) \\
\end{array}$ & - & $\begin{array}{l}10.22 \cdot 45 / 440 \\
11.36 \cdot 50 / 440\end{array}$ \\
\hline $\begin{array}{l}\text { Unreduced } \\
\text { vowels }\end{array}$ & $\begin{array}{c}27.20 \cdot 68 / 250 \\
30.80 \cdot 76 / 250 \\
(3)\end{array}$ & $\begin{array}{c}5.00 \cdot 2 / 40 \\
10.00 \cdot 4 / 40 \\
(5)\end{array}$ & - & $\begin{array}{l}24.13 \cdot 70 / 290 \\
27.58 \cdot 80 / 290\end{array}$ \\
\hline & \multicolumn{3}{|c|}{ Rate of stresses attributed to unstressed V --> } & $\begin{array}{l}9.01 \cdot 128 / 1420 \\
13.87 \cdot 197 / 1420\end{array}$ \\
\hline
\end{tabular}

Examples: (1) astronomia , 'astronomy' N; (2) $\underline{\text { bi. }} . \underline{\text { logo }}$ o, 'biologist' N;

(3) batom, 'lipstick' N; (4) clíníca, 'clinic' N;

(5) inconcretizá $\underline{\text { vel }}$, 'impossible to realise' A; (6) cama $\underline{\text { a }}$, 'bed' $\mathrm{N}$.

Taking into account the positions of the unstressed vowels that were identified as stressed, several aspects must be remarked (see Table 4). After derivational stem's last vowel (i.e. in class marker's position), only $1.30 \%$ (EP) / $1.73 \%$ (BP) of the vowels were incorrectly identified as stressed. By contrast, the percentage of last vowels of derivational stem and pre-stressed vowels considered stressed is relatively high (it is higher than the average of stresses perceived on vowels not bearing the primary stress $-9.01 \% / 13.87 \%) .11 .66 \% / 13.33 \%$ of the unstressed last vowels of derivational stem (i.e. the vowels that would be primarily stressed, if they were not lexically marked as unstressable) were perceived as stressed.

In the pre-stressed sequence, the percentages of false stresses increase as we get closer to the word primary stress: informants considered stressed $12.11 \%$ / $18.65 \%$ of the syllables immediately before the word stress, $10.00 \% / 16.00 \%$ of the second pre-stressed syllable, and $3.33 \%$ / 
$13.33 \%$ of the third pre-stressed syllables. Many of these false stresses fall on the word initial syllable $(11.53 \% / 22.11 \%)$. These may be due to the existence of an initial non-primary stress (as proposed in the literature), which was interpreted by the informants as primary stress.

The data corresponding to BP version show the same tendencies observed in the EP data, although the percentages of false stresses are, in general, much higher. No evidence for the interpretation of possible secondary stresses as primary stresses was found: the data present no tendency to a greater percentage of alternated pre-stressed syllables perceived as primarily stressed.

Table 4: Unstressed vowels that were perceived as stressed; positions of vowels

\begin{tabular}{|c|c|c|c|c|c|c|c|}
\hline \multirow[b]{2}{*}{$\begin{array}{l}E P \\
B P\end{array}$} & \multicolumn{5}{|c|}{ Pre-stressed sequence } & \multirow[b]{2}{*}{$\begin{array}{c}\text { Last vowel } \\
\text { of deriv. } \\
\text { stem }\end{array}$} & \multirow[b]{2}{*}{$\begin{array}{l}\text { After last } \\
\text { vowel of } \\
\text { deriv. } \\
\text { stem }\end{array}$} \\
\hline & $\begin{array}{c}\text { Word } \\
\text { begin- } \\
\text { ning }\end{array}$ & $\begin{array}{c}\text { 3rd } \\
\text { pre-str. } \\
\text { syll. }\end{array}$ & $\begin{array}{c}2 n d \\
\text { pre-str. } \\
\text { syll. }\end{array}$ & $\begin{array}{c}\text { Ist } \\
\text { pre-str. } \\
\text { syll. }\end{array}$ & $\begin{array}{l}\text { Rate of str. } \\
\text { assigned to } \\
\text { pre-str. } \\
\text { sequence }\end{array}$ & & \\
\hline & 11.53 & 3.33 & 10.00 & 12.11 & 10.21 & 11.66 & 1.30 \\
\hline & $\bullet 0 / 520$ & • $4 / 120$ & $\cdot 30 / 300$ & $\bullet 63 / 520$ & $\bullet 97 / 950$ & •28/240 & $\cdot 3 / 230$ \\
\hline & 22.11 & 13.33 & 16.00 & 18.65 & 16.94 & 13.33 & 1.73 \\
\hline & $\bullet 115 / 520$ & $\cdot 2 / 120$ & $\cdot 12 / 300$ & $\cdot 32 / 520$ & $\begin{array}{c}\cdot 161 / 950 \\
(1)\end{array}$ & $\begin{array}{c}\cdot 32 / 240 \\
(2)\end{array}$ & $\begin{array}{c}\cdot 4 / 230 \\
(3)\end{array}$ \\
\hline \multicolumn{7}{|c|}{ Rate of stresses attributed to unstressed V --> } & $\begin{array}{c}9.01 \\
\cdot 128 / 1420 \\
13.87 \\
\cdot 197 / 1420\end{array}$ \\
\hline
\end{tabular}

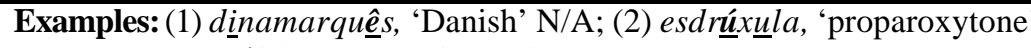
N/A; (3) república, 'republic' N, belezza, 'beauty' $\mathrm{N}$, cama $\underline{a}$, 'bed' $\mathrm{N}$

Observing now the percentages of stressed vowels that were considered unstressed (i.e. the primary stress was attributed to another vowel), and taking into account the different groups of vowels (Table 5), 
the only stressed vowel that is similar to an unreduced one ([p]) is unexpectedly almost always recognized as stressed. This may be due to the fact that there is only one word in the corpus presenting the primary stress on a phonetic [e], which is cama ('bed', N), and it has only two positions for attributing a stress: the first vowel, the real stressed one, and another vowel, being a class marker, thus hardly considered stressed.

Comparing the other groups of vowels, the unreduced vowels are more easily recognized as carrying the primary stress: the rate of vowels not identified as stressed is much lower in unreduced vowels $(14.54 \%$ / $25.75 \%)$ than in vowels not subject to reduction $(27.66 \% / 37.66 \%)$.

Table 5: Stressed vowels that were not attributed the primary stress; groups of V

\begin{tabular}{|c|c|c|c|}
\hline $\begin{array}{l}E P \\
B P\end{array}$ & & $\begin{array}{c}\text { Rate of stresses not } \\
\text { perceived on each } \\
\text { vowel }\end{array}$ & $\begin{array}{l}\text { Rate of stresses not } \\
\text { perceived on each } \\
\text { group of vowels }\end{array}$ \\
\hline $\begin{array}{l}\text { Vowel similar to } \\
\text { reduced vowels }\end{array}$ & {$[\mathrm{e}]$} & $\begin{array}{l}10.00 \bullet 1 / 10 \\
0 \bullet 0 / 10(1)\end{array}$ & $\begin{array}{c}10.00 \cdot 1 / 10 \\
0 \bullet 0 / 10\end{array}$ \\
\hline \multirow{3}{*}{$\begin{array}{l}\text { Vowels not } \\
\text { subject to } \\
\text { reduction }\end{array}$} & [i] & $\begin{array}{c}26.00 \cdot 26 / 100 \\
34.00 \cdot 34 / 100(2)\end{array}$ & \multirow{3}{*}{$\begin{array}{c}27.66 \cdot 83 / 300 \\
37.66 \cdot 113 / 300\end{array}$} \\
\hline & {$[\mathrm{u}]$} & $\begin{array}{c}35.00 \cdot 14 / 40 \\
30.00 \cdot 12 / 40(3)\end{array}$ & \\
\hline & nasals & $\begin{array}{c}26.87 \cdot 43 / 160 \\
41.87 \cdot 67 / 160(4) \\
\end{array}$ & \\
\hline \multicolumn{2}{|c|}{ Unreduced vowels } & $\begin{array}{c}14.54 \cdot 48 / 330 \\
25.75 \cdot 85 / 330(5)\end{array}$ & $\begin{array}{l}14.54 \bullet 48 / 330 \\
25.75 \bullet 85 / 330\end{array}$ \\
\hline \multicolumn{3}{|c|}{ Rate of stresses not perceived --> } & $\begin{array}{l}20.62 \cdot 132 / 640 \\
30.93 \cdot 198 / 640\end{array}$ \\
\hline
\end{tabular}

In Table 6, which presents the positions of the stressed vowels not perceived as such in single words, I considered the variables "marked vs. 
unmarked stress pattern" and "presence vs. absence of derivational suffixes with lexically determined stress". As expected, stressed vowels in marked position are more easily identified than stressed vowels in unmarked position: only $15.83 \%$ / $22.08 \%$ were not recognized as stressed in marked position, while derivational stem's last vowels not perceived as stressed total $23.50 \% / 36.25 \%$.

The stressed vowels in words with a derivational suffix lexically marked for stress are more easily identified (only 9.09\% / 13.63\% of stresses were not identified) than the stressed vowels present in suffixes not marked for stress. Words ending in nasal vowelor diphthong present a very high percentage of non-recognition of primary stress, independently of the stress pattern.

Table 6: Stressed vowels that were not attributed the primary stress; positions of V

\begin{tabular}{|c|c|c|c|c|c|c|}
\hline $\begin{array}{l}E P \\
B P\end{array}$ & \multicolumn{3}{|c|}{$\begin{array}{l}\text { Stressed V in marked position } \\
\text { (penultimate } V \text { of deriv. stem) }\end{array}$} & \multicolumn{3}{|c|}{$\begin{array}{c}\text { Stressed V in unmarked } \\
\text { position (last V of deriv. stem) }\end{array}$} \\
\hline $\begin{array}{r}\text { Word End } \\
->\end{array}$ & $\begin{array}{l}\text { Deriv. } \\
\text { morpheme }\end{array}$ & $\begin{array}{c}\text { Without } \\
\text { deriv. } \\
\text { morpheme } \\
\text { or nasal }\end{array}$ & $\begin{array}{c}\text { Nasal } \\
\text { vowel or } \\
\text { diphthong }\end{array}$ & $\begin{array}{l}\text { Deriv. } \\
\text { morpheme }\end{array}$ & $\begin{array}{c}\text { Without } \\
\text { deriv. } \\
\text { morpheme } \\
\text { or nasal }\end{array}$ & $\begin{array}{c}\text { Nasal } \\
\text { vowel or } \\
\text { diphthong }\end{array}$ \\
\hline \multirow{3}{*}{$\begin{array}{c}\text { Rate of } \\
\text { stresses } \\
\text { not } \\
\text { attributed } \\
\text { to stressed } \\
\text { vowels }\end{array}$} & $\begin{array}{c}9.09 \\
\cdot 10 / 110 \\
13.63 \\
\cdot 15 / 110 \\
(1)\end{array}$ & $\begin{array}{c}18.57 \\
\cdot 13 / 70 \\
22.85 \\
\cdot 16 / 70 \\
(2)\end{array}$ & $\begin{array}{c}25.00 \\
\cdot 15 / 60 \\
36.66 \\
\cdot 22 / 60 \\
(3)\end{array}$ & $\begin{array}{c}30.66 \\
\cdot 46 / 150 \\
39.33 \\
\cdot 59 / 150 \\
(4)\end{array}$ & $\begin{array}{c}14.28 \\
\cdot 20 / 140 \\
31.42 \\
\cdot 44 / 140 \\
(5)\end{array}$ & $\begin{array}{c}25.45 \\
\cdot 28 / 110 \\
38.18 \\
\cdot 42 / 110 \\
(6)\end{array}$ \\
\hline & & $\begin{array}{l}15.83 \cdot 38 / 240 \\
22.08 \cdot 53 / 240\end{array}$ & & & $\begin{array}{l}23.50 \cdot 94 / 400 \\
36.25 \cdot 145 / 40\end{array}$ & \\
\hline & \multicolumn{6}{|c|}{$\begin{array}{l}20.62 \cdot 132 / 640 \\
30.93 \cdot 198 / 640\end{array}$} \\
\hline
\end{tabular}

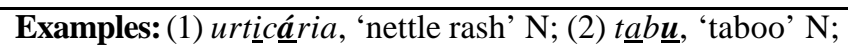

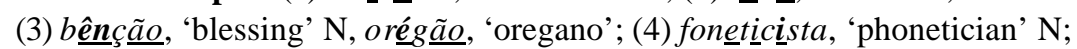
(5) $\underline{\text { alvará }}$, 'charter' $\mathrm{N}$; (6) jardim, 'garden' N. 
As far as the number of syllables available for echo stresses is concerned, a greater number of pre-stressed syllables does not lead to a larger percentage of incorrectly attributed stresses. On the contrary, less false stresses are perceived in words with more pre-stressed syllables. Considering the results of the two versions, false stresses were assigned to $2.50 \%$ of the existing pre-stressed vowels in words with four pre-stressed syllables, to $10.75 \%$ of the vowels in three pre-stressed syllables words, to $10.55 \%$ of the vowels in words of two pre-stressed syllables and to $24.77 \%$ of the vowels belonging to words with one pre-stressed syllable.

In compounds, the manipulated variables present, in general, the behaviour observed in single words. The only difference is that the percentage of stressed vowels correctly identified is lower in prosodic compounds than in single words (EP and BP, nouns and adjectives: $64.41 \%$ in compounds vs. $75.78 \%$ in single words).

The results concerning the identification of word primary stress in verbs are also similar to those registered in nouns and adjectives. For instance, proparoxytone verbal forms with an inflectional morpheme (which can be considered marked as unstressable - e.g. Andrade 1988/94 proposes that most of the tense-mood-aspect morphemes are extrametrical: 123) are almost always correctly identified - e.g. está vamos, '(we) were', 0 mistakes. Unreduced vowels are frequently incorrectly identified as stressed - e.g. invadiram, '(they) invaded', 8 stresses attributed to [a]. Primary stress perception in some verbal forms also seems to be influenced by related nouns with vowels lexically marked as unstressable e.g. nivelar $r$, 'to level', 8 stresses attributed to [i] (see nível, 'level' $\mathrm{N}$ ). 


\section{Discussion of Results}

These results suggest that the informants use the three cues lexical, morphological and phonological - to identify the primary stress. Summarizing the importance of each variable, the marked or unmarked stress pattern is an important variable (see Table 6), although it depends much on the kind of derivational morpheme. In general, the primary stress is more easily identified in words presenting a marked stress pattern.

The suffixes' stress pattern constitutes a very important variable for recognizing word primary stress. The marked pattern present in the derivational morphemes makes them helpful auxiliaries to identify word primary stress. By contrast, suffixes not lexically marked for stress do not help to identify the primary stress. The results concerning these two variables show that the lexical information is more useful to identify the primary stress than the morphology of the word.

The data also demonstrated that the vowel reduction process plays a very important role in the perception of word primary stress: the more unreduced a vowel is, the more chances it has of being considered stressed.

A greater number of syllables available for echo stresses did not appear to be very relevant, because, in longer words, there are less prestressed vowels perceived as stressed. Besides, the general tendency (in longer and shorter words) is to attribute stresses especially to the syllables closer to the last vowel of the derivational stem. This fact reveals the importance of morphology in stress perception, since the unmarked stress pattern consists in assigning stress to the derivational stem's last vowel. 
Finally, the secondary stress in compounds has only some influence on stress perception (it leads to a greater percentage of stresses incorrectly identified), because the speaker generally recognizes that the word primary stress corresponds to the rightmost stress in the compound.

Therefore, according to these results, the three cues are used to identify the word primary stress, although the lexical knowledge and the vowel reduction seem to be more helpful than the morphology alone. Despite the fact that speakers know where the primary stress is located (e.g. they always associate the tonal accents to the primary stressed syllable and they always produce "correctly stressed" words), when they have to explicitly identify its position and the three cues point out in different directions, they may become confused and unable to say which is the stressed syllable. That is when the lexical information and vowel reduction appear to function as stronger cues than the word's morphological structure. For instance, in the words with at least $90 \%$ correct responses these three cues are not contradictory: almost all the unstressed vowels are reduced and almost all the stressed vowels are open; $61.54 \%$ of these words present a marked stress pattern (53.85\% having a lexically marked suffix).

Summing up the arguments for these interpretations, the importance of morphological knowledge in the perception of word primary stress is supported by the following facts: (i) an average of $72.40 \%$ of stresses are correctly identified (and the position of primary stress is mainly morphologically determined); (ii) class markers are very seldom assigned a stress; (iii) most stresses incorrectly identified are attributed to one of the two possible localizations for word primary stress; (iv) the 
speakers seem to be aware of stress variable localization; and (v) in longer words the speakers know that a vowel is more likely to be stressed if it is closer to the last vowel of the derivational stem.

The facts (ii), (iii) and (v) could be interpreted as consequences of some rhythmic notions concerning Portuguese. However, the facts that rhythm alone cannot explain Portuguese stress position (it implies dso some morphology) and that speakers correctly identify stresses localized on the last, penultimate or antepenultimate syllable lead me to consider all these results as evidences for morphological knowledge supporting the perception of word primary stress.

Lexical knowledge (recognition of vowels lexically marked as unstressable) is also an important cue for three reasons: (i) derivational morphemes with vowels lexically marked as unstressable help the primary stress's identification; (ii) marked stress patterns are generally more easily recognized; and (iii) the lexically determined stress of some nouns and adjectives influences the stress perception in some verbal forms.

The following facts also support the importance of vowel reduction in the perception of word primary stress: (i) in the EP version the unstressed vowels more often perceived as stressed are unreduced vowels, followed by vowels not subject to reduction and by reduced vowels; (ii) the unreduced vowels are more easily recognized as stressed than the vowels not subject to reduction; (iii) in the BP version, many false stresses were assigned to the vowels corresponding to reduced vowels in EP (i.e., vowels often produced as unreduced in BP); and (iv) the rate of stresses correctly identified is lower in the BP version (variety of Portuguese presenting less vowel reduction). 


\section{Conclusions}

By showing the importance of the morpholexical information and the vowel reduction process to the perception of word primary stress by EP speakers, these results confirm what most literature has said about the word primary stress in Portuguese (it is morpholexically conditioned), give empirical evidence for the existence of vowels lexically marked as unstressable, and show the function of vowel reduction on unstressed vowels (to establish an hierarchy of vowels in the word so that the word primary stress can be more easily identified).

However, these results lead us to another question: do the EP native speakers really need the stress acoustic correlates to identify the word primary stress, or do they perform this task only using their linguistic knowledge? In other words, do the EP native speakers present stress "deafness" (cf. Peperkamp and Dupoux 2002)? Speculatively, they present a certain stress "deafness", that is different from the one presented by native speakers of languages in which stress is phonologically predictable (e.g. French). Their "deafness" may be characterized by being able to correctly use a contrastive stress and, at the same time, having difficulties in saying which is the stressed syllable, in making that knowledge explicit. The linguistic knowledge they have may allow them to use contrastively the primary stress without "hearing" the stress acoustic correlates. Consequently, when the linguistic cues seem to be contradictory, they can become confused. However, so as to answer these questions, another 
experiment, with (non-existing) words presenting none of the cues identified in this investigation, is needed.

\section{Acknowledgments}

Research for this paper was funded by a grant from the Project "Understanding Phonology" (FCT, POCTI/33277/LIN/2000). I am also grateful to Maria Helena Mateus, Ernesto d'Andrade, Marina Vigário, John Kingston, Manuel DíazCampos, my colleagues (especially Susana Cabeleira and Susana Correia) and two anonymous reviewers, for comments and discussion.

\section{Notes}

${ }^{1}$ In this paper, in order to analyse the results, I mention "stresses incorrectly identified" and "mistakes". When I do that, I assume that: (i) there is only one stress that can be considered the word primary stress (some vowels can have some degree of stress that, nonetheless, does not correspond to the primary one); (ii) the primary stress of the words heard by the informants is in accordance with the predictions of primary stress's rules; and (iii) there is no process (e.g. destressing or stress movement) justifying a different perception of the primary stress.

2 The word primary stress acoustic correlates' in EP were already identified by Delgado Martins (1982: 98) as being the duration and the energy in the ultimate and antepenultimate syllables. When the stressed syllable is the penultimate one, there is no stress acoustic correlate, which Delgado Martins relates to the fact that the stress on this syllable corresponds to the unmarked pattern in Portuguese.

3 In the examples presented, the word primary stress is graphically represented in bold and underlined, while the secondary stresses or incorrectly attributed stresses are only underlined. Since the only relevant point in this paper is the place of stresses, the examples are not phonetically transcribed.

${ }^{4}$ There are, however, some exceptions concerning the vowel [i], in EP, which we will not present because they are not relevant to this work. For further information, see Vigário 2003.

${ }^{5}$ The non-graduated informants studied eleven or twelve years at school, while the graduated women concluded twelve years at school and, after that, they made four to six years of studies in the University.

${ }^{6}$ In Tables 3 to 6, the EP results are presented in the first line and the BP ones in the second line. The initial number corresponds to the rate (of vowels incorrectly perceived as stressed or incorrectly perceived as unstressed) in percentage, while the number preceded by $(\bullet)$ presents the raw error values. 


\section{References}

Andrade, Ernesto d' 1994 O acento de palavra em português. In Temas de fonologia [Themes of Phonology], Ernesto d'Andrade, 107-130. Lisbon: Colibri.

Andrade, Ernesto d' and Maria do Céu Viana 1999 Constantino e os acidentes de Constantinopla: os acentos do Português e do Castelhano. In Linguística Computacional: Investigação Fundamental e Aplicações [Computacional Linguistics: Fundamental Investigation and Applications], Palmira Marrafa and Maria Antónia Mota (eds.), 79-95. Lisbon: APL/Colibri.

Callou, Dinah and Yonne Leite $1990 \quad$ Iniciação à Fonética e à Fonologia [Initiation to Phonetics and Phonology]. Rio de Janeiro: Jorge Zahar Editor.

Delgado Martins, Maria Raquel 1982 Aspects de l'accent en portugais. Hamburg: Helmut Buske Verlag.

Frota, Sónia and Marina Vigário 2000 Aspectos de prosódia comparada: ritmo e entoação no PE e no PB. In Actas do XV Encontro da Associação Portuguesa de Linguística, Vol.1, [Proceedings of the XV National Meeting of the Portuguese Association of Linguistics] Rui Vieira Castro and Pilar Barbosa (eds.), 533-555. Coimbra: APL.

Mateus, Maria Helena, Ana Maria Brito, Inês Duarte, Isabel Hub Faria, Sónia Frota, Gabriela Matos, Fátima Oliveira, Marina Vigário, Alina Villalva 2003 Gramática da Língua Portuguesa [Grammar of the Portuguese Language]. Lisbon: Caminho.

Mateus, Maria Helena and Ernesto d'Andrade 2000 The Phonology of Portuguese. Oxford: Oxford University Press.

2002 A typological study

Peperkamp, Sharon and Emmanuel Dupoux Carlos Gussenhoven and Natasha of stress 'deafness'. In Laboratory Phonology 7, Carlos Gussen

Vigário, Marina 2003 The Prosodic Word in European Portuguese. Berlin/New York: Mouton de Gruyter. 